\title{
LETTERS
}

\section{Hepatitis B vaccination for Canadian children: time for an adult conversation}

The recent article by Biondi and colleagues described the epidemiology of the hepatitis $B$ virus (HBV) and $H B V$ vaccination in Ontario. ${ }^{1}$ The authors concluded that there is substantial opportunity for improvements in prenatal screening, diagnosis and infant vaccination for hepatitis $B$ in the province.

Despite the implementation of universal HBV vaccination in Canada more than 25 years ago, there remain disparities in vaccination schedules across the country (i.e., www.canada.ca/content/dam/phac-aspc/ documents/services/provicial-territorial -immunization-information/childhood -vaccination-schedule-2020.pdf). The World Health Organization recommends universal birth dose vaccination for HBV within 24 hours of birth, and has set a 2030 target that $90 \%$ of infants worldwide receive 3 doses of vaccine. Canada is not on track to achieve this goal. A 2017 study found that by age 7 , only $74.5 \%$ children in Canada had received 3 doses of HBV vaccine. ${ }^{2}$ However, regions implementing birth dose vaccination, such as Nunavut, have shown success in reducing HBV prevalence to below endemic levels ${ }^{3}$ (as in the rest of Canada). Implementing a national standardized schedule would continue these successes and allow for harmonized monitoring of pediatric HBV infection.

Our recent study highlighted the demographics of people living with HBV in Canada, most of whom were born outside of Canada. ${ }^{4}$ The 2016 Canadian Census results show that more than $30 \%$ of children were born, or have parents who were born, outside of Canada, often in HBV-endemic regions. Given changing Canadian demographics, Canada should join the other 97 countries $^{5}$ that have already introduced the universal birth dose vaccination for HBV.

\section{Carla S. Coffin MD MSC}

Associate professor, Division of Gastroenterology and Hepatology, Department of Medicine, Cumming School of Medicine, University of Calgary, Calgary, Alta.

\section{Carla Osiowy PhD}

Chief, Viral Hepatitis and Bloodborne Pathogens Section, National Microbiology Laboratory, Public Health Agency of Canada, Winnipeg, Man.

Cite as: CMAJ 2021 January 4;193:E26. doi: $10.1503 / \mathrm{cmaj} .77356$

\section{References}

1. Biondi MJ, Marchand-Austin A, Cronin K, et al. Prenatal hepatitis B screening, and hepatitis B burden among children, in Ontario: a descriptive study. CMAJ 2020;192:E1299-305.
2. Public Health Agency of Canada. An Advisory Committee Statement (ACS), National Advisory Committee on Immunization (NACl): update on the recommended use of Hepatitis $B$ vaccine. Ottawa: Public Health Agency of Canada; 2017. Available: www.canada.ca/en/public-health/ services/publications/healthy-living/update -recommended-use-hepatitis-b-vaccine.html (accessed 2020 Oct. 26).

3. Huynh C, Minuk GY, Uhanova J, et al. Serological and molecular epidemiological outcomes after two decades of universal infant hepatitis $B$ virus (HBV) vaccination in Nunavut, Canada. Vaccine 2017;35:4515-22.

4. Coffin CS, Ramji A, Cooper CL, et al. Epidemiologic and clinical features of chronic hepatitis $B$ virus infection in 8 Canadian provinces: a descriptive study by the Canadian HBV Network. CMAJ Open 2019;7:E610-7.

5. World Health Organization. WHO position paper on hepatitis B vaccines - July 2017. Wkly Epidemiol Rec 2017;92:369-92.

Competing interests: None declared.

Content licence: This is an Open Access article distributed in accordance with the terms of the Creative Commons Attribution (CC BY-NC-ND 4.0) licence, which permits use, distribution and reproduction in any medium, provided that the original publication is properly cited, the use is non-commercial (i.e. research or educational use), and no modifications or adaptations are made. See: https://creativecommons.org/ licenses/by-nc-nd/4.0/

Disclaimer: The views and opinions expressed in this letter are those of the authors and do not necessarily reflect the official policy or position of the University of Calgary or the Public Health Agency of Canada. 